\title{
EVALUATION OF A NATIONAL LEVEL SCHEME FOR UPLIFTING RURAL POPULATION THROUGH FINANCIAL INCLUSION IN A DEVELOPING COUNTRY: EVIDENCES FROM RURAL INDIA
}

\author{
Utkarsh Goel \\ Assistant Professor \\ Department of Management Studies \\ Indian Institute of Information Technology, Allahabad, India \\ E-mail: utkarsh@iiita.ac.in \\ Shailendra Kumar \\ Associate Professor \\ Department of Management Studies \\ Indian Institute of Information Technology, Allahabad, India \\ E-mail: shailendrak@iiita.ac.in
}

Received: August 30, 2021

DOI: $10.46281 /$ ijfb.v8i1.1476
Accepted: October 14, 2021 Online Published: December 05, 2021

URL: https://doi.org/10.46281/ijfb.v8i1.1476

\begin{abstract}
This study aims to understand the factors that encourage the people from rural background to access the banking Services offered under a financial inclusion scheme, with evidences from a developing country, India. Pradhan Mantri Jan Dhan Yojana (PMJDY), scheme launched by Government of India, has an objective of connecting the banking industry with the people residing in the remote areas of the country. The research is aimed to gauge the PMJDY's accomplishments in terms of fulfilment of its objectives. The research helps in getting a ground level feedback of the financial inclusion schemes' achievements and issues involved in its successful implementation. This study also explores the perceptions of the individuals regarding the benefits offered by the scheme. A field survey of 2446 respondents was conducted in Purvanchal region of Uttar Pradesh, India. The questionnaire was constructed based on the theoretical model built after an extensive review of literature in the field of financial inclusion. The results from the analysis indicate that the awareness about the scheme and support by authorities are the two major factors that contribute to the successful implementation of a financial inclusion scheme. Overall awareness and availing of banking services under PMJDY scheme has been initiated but not uniformly.
\end{abstract}

Keywords: Financial Inclusion, Rural Upliftment, Developing Countries, Program Evaluation.

JEL Classification Codes: O10, G20, G21.

\section{INTRODUCTION}

In the present scenario, financial inclusion has been considered as one of the most important aspects for the inclusive growth and financial development of the societies (Ali et al., 2021). Financial inclusion means the delivery of financial and banking services along with credit to a vast low-income group at an 
affordable cost (Chhabra, 2015). Financial inclusion concentrates on the participation of the vulnerable groups that consist of low-income groups and weaker sections of the society based on their reach and access to the financial services such as payment and saving accounts, pensions and credit insurances (Singh et al., 2014).

Evidences from macroeconomics state that the countries with high degree of financial inclusion tend to improve local economic activity, reduce income inequality and grow faster (Beck, DemirgüçKunt, \& Levine, 2007). Hence development of financial inclusion system is an important agenda for economic and social progress. Various studies have been conducted to compare the impact of financial access at the local economy level with the baseline of quasi experimental setting. Self-help groups, microfinance institutions and accessibility to the formal finance institutions provide a better financial model and better penetration has been provided by the adoption of new models and recent technologies.

Research and policy debates have put on emphasis on the access to the credit while there is requirement of access to full range of financial services by the poor and marginalised groups to effectively manage their economic lives. Often weaker sections of the society (such as - the poor, women and rural populations) are deprived of wage-earning employment opportunities thus living and working in informal economy with least access to the formal systems and operating through borrowings from relatives, friends, money-lenders, saving schemes or money under the mattress. Such informal systems are abundantly available as well as they are very expensive and unreliable. Hence financial inclusion has high opportunity cost and offers a probable solution or the masses suffering from it. The combined effect of high transactional costs and information asymmetries put poor in bad equilibrium of deficient collateral or credit histories (Cull, Ehrbeck, \& Holle., 2014).

India, a country of 1.33 billion people living in 29 states and seven union territories with 733 districts and more than 600,000 villages (The World Bank (TWB), 2020). A vast majority of population has been deprived of the easy access to the finance, especially the population residing in rural India

(Gounasegaran, Kuriakose \& Iyer, 2013). There has been a global concern for the accessibility, affordability and price appropriateness of the financial services thus making financial inclusion an important requirement not only in India but also a primary policy concern in various countries. Access to the financial will be a major contributor in upliftment of the financial condition and living standards of the poor and deprived sections. Reserve Bank of India has been constantly promoting the extension of banking services by setting up new branches and installation of new ATMs (Dangi \& Kumar, 2013).

According to Global Findex, about 62 percent adults on the global level were having bank account. While this was only 53 percent in India (Demirguc-Kunt et al., 2015), but there has significant growth in bank account of about 80 percent has been recorded due to the introduction of schemes such as Pradhan Mantri Jan Dhan Yojana (PMJDY). As the data released by the government, as of 11th March 2020, 38.26 crore accounts have been opened under the Pradhan Mantri Jan Dhan Yojana (PMJDY, 2020) that clearly states that still a large unbanked population resides in India, which could be potential target in the coming years.

The two main factors of financial instability are geographic exclusion (exposed through distance, inaccessibility and depravity of proper infrastructure) and social exclusion (exposed through caste barriers and illiteracy). Cooperative sector and commercial banks in India were historically vested with the responsibility of financial inclusion in rural areas but have failed to fulfil the required objectives. The major features that made a majority of population unbanked can be outlined as informal employment, inability of rural population to communicate and negotiate with the formal system and deficiency of collateral. The deficient collateral and institutional credit limit acted as a barrier for the farmers to borrow from the formal system. According to the Socio-economic Caste Census 2011, more than 50 percent of the rural Indian population is dependent on the manual causal labour and about 30 percent are dependent on cultivation for livelihood (Reserve Bank of India, 2015). In a survey conducted by All-India Debt and Investment Survey, it was found that in the year 2012, more than 44 percent of the rural households were dependent on the informal credit agencies (Reserve Bank of India, 2015) although this number has significantly reduced by the market reforms providing access to more formal systems an initiatives taken by the government. 
The Government of India has recently launched Pradhan Mantri Jan Dhan Yojana (PMJDY) on Independence Day in the year 2014. With the slogan 'MeraKhata - Bhagya Vidhata' in the Independence Day speech, the Prime Minister of India launched PMJDY as 'People's Wealth Scheme' (Mohan, 2014). Pradhan Mantri Jan Dhan Yojana (PMJDY) is a comprehensive programme towards financial inclusion with aim of providing pension and insurance facilities and opening of approximately 7.5 crore new bank accounts within a duration of 5 months as of now in the year 2020 it has raised to 29.30 crore (PMJDY, 2020). The accounts opened under PMJDY scheme will be provided with life insurance of 30,000 INR, an overdraft limit amounting to 5,000 INR and accidental insurance amounting to 100,000 INR but the benefits can only be availed by the account holders who have used the made transactions through this account in 45 days earlier to the claim date. The PMJDY provide beneficiaries with a Rupay card that provides an overdraft limit amounting to 5000 INR and an accidental insurance of 100,000 INR. As a step towards financial inclusion, a transaction history will be created for the beneficiaries using debit card for the unbanked population.

Within the purview of this study it is focussed that whether the state performances are align with central objectives of PMJDY. For this purpose Uttar Pradesh a largest state (population wise) of India it taken as sample for project study. The findings of the study will call for reconciliation and evaluation of the govt. policies for the states and central as whole and hence in diverse countries like India, financial inclusion will be viewed with a holistic view providing a spectrum of services, thus encapsulating various dimensions of the targeted population.

\section{REVIEW OF LITERATURE}

Financial inclusion has been defined as "the absence of both price and non-price barriers in the use of financial services" (Demirgüç-Kunt, Honohan, \& Beck, 2008). The Committee on financial inclusion in India, chaired by Dr. C. Rangarajan defined financial inclusion as, "the process of ensuring access to financial services and timely and adequate credit where needed by vulnerable groups such as weaker sections and low-income groups at an affordable cost".

Financial inclusion can be regarded same as banking inclusion since banks are the co-ordinator of majority of the financial services (Chakravarty \& Pal, 2013). As a matter of fact, the definition of financial inclusion states that," Delivery of affordable banking services to broad sections of deprived and low-income groups" (Leeladhar, 2006). Inability to financial accessibility leads to inequality in earning opportunities and poverty traps and hence financial inclusion forms the core of the economic development (Banerjee \& Newman, 1993; Aghion \& Bolton, 1997; Beck, Demirgüç-Kunt, \& Levine, 2007; Allen et al., 2016). Many researchers have been conducted that propose a common viewpoint that providing a wide range of financial services can lead to enhancement of individual savings, investment productivity, women empowerment and upliftment of lifestyle (Aportela, 1999; Ashraf, Karlan, \& Yin, 2010).

(Beck, Demirgüç-Kunt, \& Levine, 2007) in their study developed cross-country indicators of outreach of the banking system that are comparable and consistent. The study categorised these indicators in two dimensions i.e. usage of banking services and access to bank services. The indicators to measure the access to the bank services are- geographic bank penetration, geographic Automatic Tailor Machine (ATM), demographic bank penetration, and demographic Automatic Tailor Machine (ATM) penetration. To measure usage of bank services following indicators are used- deposit accounts per capita, credit accounts per capita, deposit-income ratio and credit-income ratio. The study empirically establishes that there exists a positive relationship between outreach of the banking sector and financial services usage.

(Mialou, Amidzic, \& Massara, 2017) in their research measured financial inclusion through two variables namely usage and outreach of financial inclusion. The financial inclusion usage has been measured by- total number of borrowers and depositors per 1000 adults. The outreach variable of financial inclusion has been measured by the number of bank branches and Automatic Tailor Machine per 1000 square kilometres. Composite index of financial inclusion is calculated by aggregating 
weighted geometric mean to rank the countries based on their financial inclusion score. The issue of imperfect substitutability between the dimensions has also been addressed by this index.

Researchers studying financial inclusion have explored the relationships existing between specific individual variables and financial inclusion and identified indicators for consideration of household/indicators as financially included. Financial services in 123 countries across 124,000 individuals have been measured by Allen et al. (2016) though three indicators namely (i) individual/joint account ownership (ii) saving account usage (iii) frequency of account usage. The estimation of relationships between individual and country level variables and financial inclusion has been made in the study by the use of several Probit models. The study found a positive correlation between financial inclusion and the environment that facilitates better access to financial services such as bank branches proximity, reduced cost of banking, lesser requirement of documents, low-fee accounts offered by government and government payment through the use of bank accounts.

The three indicators used by Allen et al. (2016) have been also used by Demirguc-Kunt et al. (2015) for the measurement of financial services in 148 economies and 150000 adults in the year 2011. The indicators used in the two studies were- likelihood of possessing an account, account usage probability for savings and likelihood of account usage frequency. The study found that around half of the adult population around the world do not possess bank accounts and a wide variation in the account penetration has been observed across regions. One of the key findings of the research is that there is involuntary exclusion of 35 percent adults due to lack of documentation, physical distance and high cost of banking.

Honohan (2004) analysed the relationship between poverty, financial development and growth. He selected 70 developing countries based on the availability of poverty data and conducted a cross sectional analysis. The study found that there was a relationship between the lower poverty and financial systems or we can say that penetration of banks lead to finance-intensive growth that in turn led to the decline of poverty ratios. Financial development is not only based on the penetration of the banking services as a sole component. It was also highlighted that finance played four key roles namely capital allocation, savings mobilisation, entrepreneurial monitoring of the loanable funds and risk mitigation through repackaging and pooling. The study also argues that banking cannot be used as a sole scale to measure the comprehensive development of financial system to measure its function performance efficiencies and effectiveness.

Financial services are only accessible to small fraction of population in the developing nations. Although with the growth of these economies, financial sector is also expanding but there is concentration of financial assets in few hands. In the developing economies, majority of population is not having savings bank account, possess no insurance policies and receive no credit from the formal financial institutions. The demand and supply aspects of the financial inclusion have been studied by Kumar \& Mishra (2011) to evaluate the level of financial inclusion with respect to the outreach of banking services and their accessibility at household level in India. Three dimensions proposed by Sarma (2008) i.e. availability, access and usage have been used to measure the banking outreach. The accessibility at the household level has determined by the level of knowledge the households have about the credit services, insurance and informal and formal savings. The study found there was huge variation in demand and supply side performance across sates and urban and rural areas.

Researchers (e.g. Dangi \& Kumar (2013) have also studied the initiatives taken by Government of India and policies measures taken by RBI and augmented that for capacity building and building capacity can be boosted by the adoption of the fundamental financial offerings by the banking sector and availability of the credit facility (Sen, 2000). Suryanarayana (2008) emphasized on defining the exclusion/inclusion based on the outcomes based on the growth scenario that reflected the estimates of production, distribution, consumption and income. The study helps in profiling of the people based on their region, society and occupation that have been excluded from the mainstream growth process. Hence the study attempts to propose measures for inclusion based on the distribution of consumption pattern for the year 2004-2005. Agrawal (2008) adopted behavioural perspective for studying financial inclusion from the viewpoint two variables i.e. demand and supply. The study proposed scope to marketers and 
policy makers from the behavioural perspective for the alignment of their approaches with the behavioural aspect.

In the year 2003, the policy of Reserve Bank of India on financial inclusion aimed at providing accessibility of the financial services to the unprivileged that can be considered as one of the bold moves to provide financial inclusion to the target consumers. Rangarajan Committee was formed in 2008 on financial inclusion was of the view that it is crucial to sustain the unprivileged population through financial inclusion and acceleration in growth momentum. To achieve the objective, the committee came up strategies such as rejuvenation of the Cooperative and RRBs, establishment of National Mission on financial inclusion, introduction of Business Facilitator and Business Correspondents Model and introduction of MFI model (SHG-Bank linkage). Mukherjee \& Chakraborty (2012) in their research studied the role played by commercial banks in the state of Jharkhand and analysed their capacity and efficiency in comparison with the institutions such as non-banking financial companies (NBFCs), SelfHelp groups (SHGs) and regional rural banks (RRBs) with the purpose of promotion of financial inclusion. The study found that the failed to achieve the desired objectives and the study recommended that the frequency of financial inclusion Report to RBI by every bank should increase. HR \& KN (2013) in their study analysed the role of Self-Help Groups in financial inclusion and found that as the membership to SHGs increased, an increase in financial inclusion was also observed. Also, the increased membership to SHGs had a positive impact over the opening of bank accounts, credit availed and loans repayment by the members.

(Joseph \& Varghese, 2014) studied the impact of financial inclusion over the development of Indian economy with the help of growth rate of the banks that were reflected by the number of bank branches and credit and debit card usage. It was found that through the study period there was tremendous increment in the debit card usage but the accessibility to the products and services offered by the bank was continuously limited even after passage of significant duration since financial inclusion initiative in the country. Paramasivan and Ganeshkumar (2013) in their study on financial inclusion in India found that the financial inclusion is significantly impacted by the branch density. Sriram and Sundaram (2015) in their research studied the rural areas of Vellore in Tamil Nadu to identify the variables impacting financial inclusion. The study collected data from 20 village blocks in Vellore and outlined the constraints and reasons for lower rates in bank account opening. By the use of statistical techniques such as percentage analysis and index of financial inclusion, the level of financial inclusion in Vellore was found to be in mid-range of 0.55. The major constraints in access to financial services have been identified as unemployment and lower level of literacy and income. Another study was conducted in the state of Karnataka based on a report that claimed the level of financial inclusion in the district of Gulbarga was 100 percent. The results of the study were different from the ones claimed in the report and it was found that the accounts opened in the banks were not under the program of financial inclusion rather they were opened under NREGP scheme. The awareness about financial inclusion has been constantly low and thus there is need to take initiatives that spread more awareness (Ramji, 2009). The tripod of the financial inclusion in shown in figure 3 that has been laid by RBI. There has been much focus given to the financial inclusion while other two components were used as a means to attain the primary objective. A cross country analysis was conducted by two researchers and they found that level of financial inclusion had a positive correlation with level of human development. Components such as urbanization, levels of literacy and income inequality were also identified as contributors in explaining financial literacy (Sarma \& Pais, 2011).

Gloukoviezoff (2007) from this research found that individual's self-esteem is affected when he/she does not possess a bank account and hence feels isolated and socially disconnected from family and friends. Such social implications arise when formal institutions exclude them from credit and as a result such population tends to fall in the clutches of private money lenders and loan sharks. Also, there have been incidents recorded where violent and harsh methods of loan recovery have been adopted by the moneylenders and informal institutions. In 2010 due such practices of loan recovery, microfinance sector has been viewed in bad light. In the state of Andhra Pradesh certain providers of microfinance in their quest to outreach and capture the unserved population used unethical practices of charging very 
high interest rates and strong-arm practices to recover loans the led to complete closure of microfinance operations in Andhra Pradesh (Shylendra, 2006; Sriram, 2012). In India, microfinance sector has suffered serious setbacks from the stories where around 40 cases of suicide in Andhra Pradesh came into light and the reason of these suicides was due to over-indebtedness from the microfinance sector. The consequences were reflected over the whole microfinance sector across the country that was evident from significant decrease in loan portfolio and client outreach for the year 2011-12 (Sriram, 2012).

In Uttar Pradesh total no. of bank beneficiaries comes to $62,473,876$, with balance in account $24,809.42$ crore rupees and 100 percent household coverage. The state has more than 30 percent of its total deposit in banks comprise under PMJDY schemes that reveals a huge success and reflecting a progress year on year (PMJDY official website). Pradhan Mantri Jan Dhan Yojana (PMJDY) also helps in uplifting the social status of the unbanked people by bringing in the main banking stream through financial inclusion. One of the core objectives of the PMJDY is to deliver the financial benefits such as subsidies to the bank accounts of the beneficiary thus curbing any short of corruption in the transactions (Chowhan \& Pande, 2014). Government and banks have launched a collaborative effort to launch massive financial literacy campaigns to spread a holistic awareness among the poor and deprived sections of the population as part of PMJDY core objective. Creating better understanding of the financial inclusion schemes such as Jan Dhan Yojana thus making a large population financially literate and enables them to avail advantages and responsibilities attached with such schemes.

This research is dedicated to verifying the roles of government and banks in claiming all such above mentioned core objectives of financial inclusion schemes, with evidences from the PMJDY scheme launched in India. This is an attempt to gain a glimpse of current status of milestones covered under the scheme with ground reality and verifying whether all intended PMJDY beneficiaries understand their statutory obligations before claiming the benefits / rights under the scheme. It helps to understand that despite of considering financial inclusion as a compulsion, whether banks in urban, semi urban and rural areas consider it as a business opportunity and utilise in expanding the financial system of the nation. Also whether government and banks are able provide protection to financial weaker sections from being exploited by the moneylenders and enhance the effectiveness of the unorganized sectors.

\section{RESEARCH DESIGN}

The essence of financial inclusion is to ensure delivery of financial services which include bank accounts for savings and transactional purposes, low cost credit for productive, personal and other purposes, financial advisory services, insurance facilities (life and non-life) etc. Financial inclusion will be successful only when the easy accessibility to financial services is complemented by financial awareness and understanding.

Under PMJDY scheme, the financial services being offered can be broadly classified into following three categories:

- Basic Banking Services

- Credit facility

- Financial security products

Moreover, it is also proposed in PMJDY, to channel all Government benefits (from Centre/State/Local body) to the beneficiaries of the scheme through Direct Benefit Transfer (DBT). 


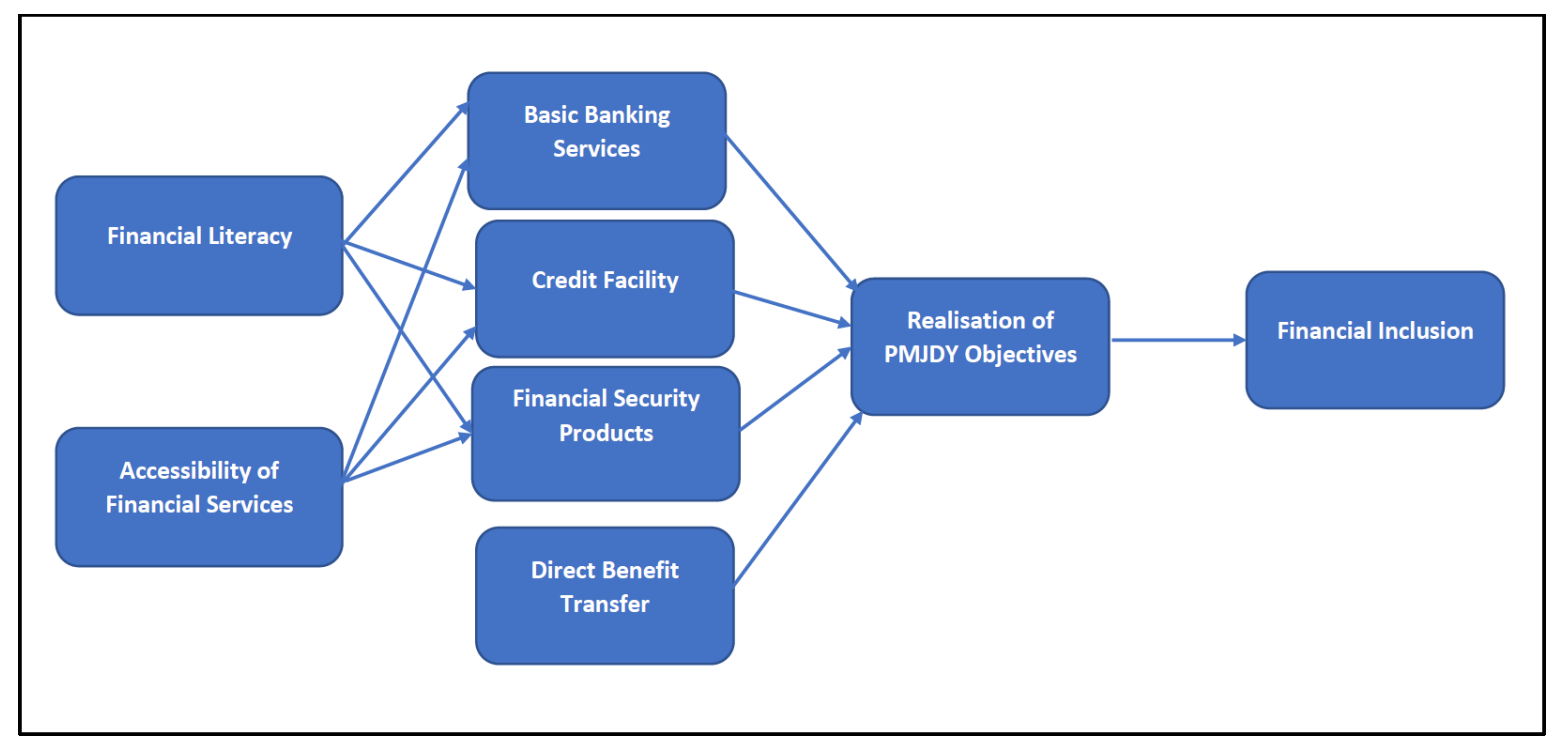

Figure 1. Conceptual Framework

The factors determining the success of the PMJDY scheme have been studied from two angles. First the factors like Awareness, Ease of Availing, Usefulness to life, Bank support, Local Administration support and, facets of scheme benefits are studied and then the perceptions of the individuals regarding the benefits offered by the scheme have been explored. For this, the benefits of the financial inclusion schemes such as standard of living, prevention of exploitation, improving financial literacy, safety of money, making transactions online and, investment opportunities are taken as the independent variables. A dependant variable named Availing status has been introduced to ascertain whether the respondent is availing the facilities offered by the PMJDY scheme.

A draft questionnaire was prepared. Taking into consideration the demography, the questionnaire was prepared both in English and Hindi language. It consisted of 14 Questions mostly choice based objective type for easy understanding by the respondents and coverage of the objectives. The questionnaire consisted of mostly dichotomous and 3-point Likert scale questions for understanding the sensitivity of the issues involved. The draft questionnaire was sent to academic experts in the area for getting feedback and was modified accordingly. Considering the heterogenous educational, occupational and income background of the respondents, the sensitivity in the objective based questions have been kept low at 3-point Likert scale. Some of the questions were even made dichotomous for easy understanding and for cross analysis of data.

\section{DATA COLLECTION}

The required information for the study was collected from PMJDY beneficiary households of urban and rural population of U.P. Purvanchal region. Purvanchal is a geographic region of north-central India, which comprises the eastern end of Uttar Pradesh state. Uttar Pradesh is the most populous state in India with a population of $\sim 200$ million people. As much as $16.17 \%$ of India's population lives in the state. The central and eastern districts of Uttar Pradesh in particular have very high levels of poverty. The pace of poverty reduction in the state has been slower than the rest of the country. Most of the occupational groups within the population of Uttar Pradesh are involved in agriculture and service industries, which contribute to the largest parts of the state's economy. Unskilled labourers form a major portion of the work force.

Sample size was decided after getting the detailed geography of Purvanchal Region. Looking at the demography of Purvanchal region, it was observed that the region is divided into 21 districts containing 101 tehsils. It was decided to collect on an average 25 respondent data from each Tehsil of Purvanchal region. Hence the target sample size was (101 x 25) 2550. Out of the target we were finally able to get useful responses of 2446 respondents. 


\section{DATA ANALYSIS AND RESULTS}

The data collected through questionnaire was filtered and transformed in order to make it suitable for analysis. The data, thereafter, was analysed and interpreted using various statistical tools and techniques. Regression modelling was applied as required to confirm the relationships.

\section{Descriptive Analysis}

The distribution of data shows that the respondents consisted of $60 \%$ Male and $40 \%$ Female (Figure 2). Age wise distribution shows that the PMJDY scheme is more known among old age group i.e. 55 years and above. In addition the young people ( 25 to 39 years) who may be more tech savvy, earning and more aware are also found to be attracted towards the PMJDY scheme (Figure 3). Most people came to know about the scheme through word of mouth from their friends and relatives (Fig. 4). Data shows that people have less information about financial security benefits and credit facility available under the scheme. DBT seems to be very popular and almost $80 \%$ respondents said that they have at least some information about this facility (Figure 5). Special facility like overdraft is unknown to almost all respondents. Full information is available to few people only and it is mostly related to basic banking facilities only. Direct benefit Transfer scheme also shows the high availing status with almost $60 \%$ people availing the same. High stress on the success of DBT by the government is evident from this result. Credit Facility by way of overdraft shows $0 \%$ availing status, which clearly indicates that people were not able to avail any credit facility under the scheme (Figure 6). Other banking facilities like money transfer and Mobile banking have not been availed to great extent and only about $20 \%$ to $37 \%$ people say that they have been availing these facilities. Financial security facilities like Accidental insurance and Life Insurance have also shown negligible usage with less than $20 \%$ people mentioning that they have been able to use the same. Respondents have found easiness in using the basic banking facilities and thus more than $40 \%$ people have agreed that the scheme benefits were easy to avail (Figure 7). More than almost $90 \%$ people have the opinion that they have not received any local administration support in availing most of the benefits under PMJDY. Especially in case of Basic Banking services, respondents feel that banks have been very supportive with the majority saying that banks were supportive in nature (Figure 8). While in case of other facilities like credit facility, financial security benefits and other banking facilities, respondents have not found banks to be supportive. Even in case of DBT, people feel that banks are not supporting them in availing the facility. More than almost $90 \%$ people have the opinion that they have not received any local administration support in availing most of the benefits under PMJDY (Figure 9). For benefits like financial literacy, online transactions and easy investment opportunities, almost 50\% or more people have agreed that these have been received by them due to PMJDY scheme. In others like Standard of living and preventing of exploitation also more than $25 \%$ agree that these have been received by them.

\section{Gender wise Awareness}

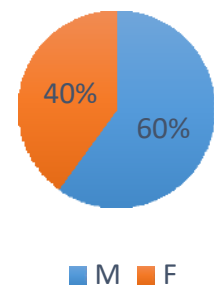

Figure 2. Gender wise distribution of the data 


\section{Age Wise Awareness}

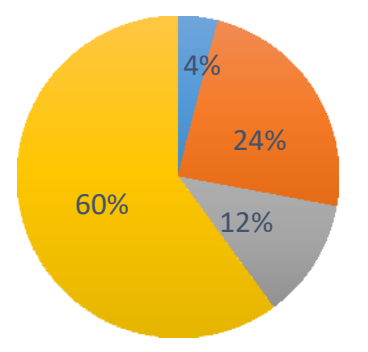

10-24 Yrs 25-39 Yrs 40-54 Yrs > 54 Yrs

Figure 3. Age wise distribution of data

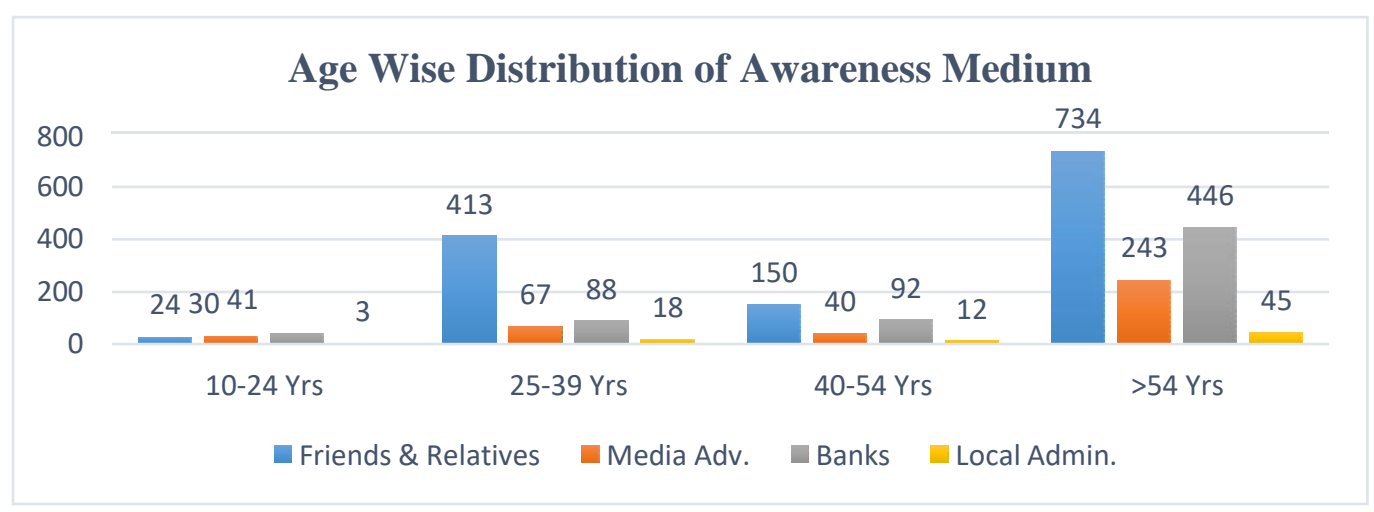

Figure 4. Age Wise Distribution of Awareness Medium

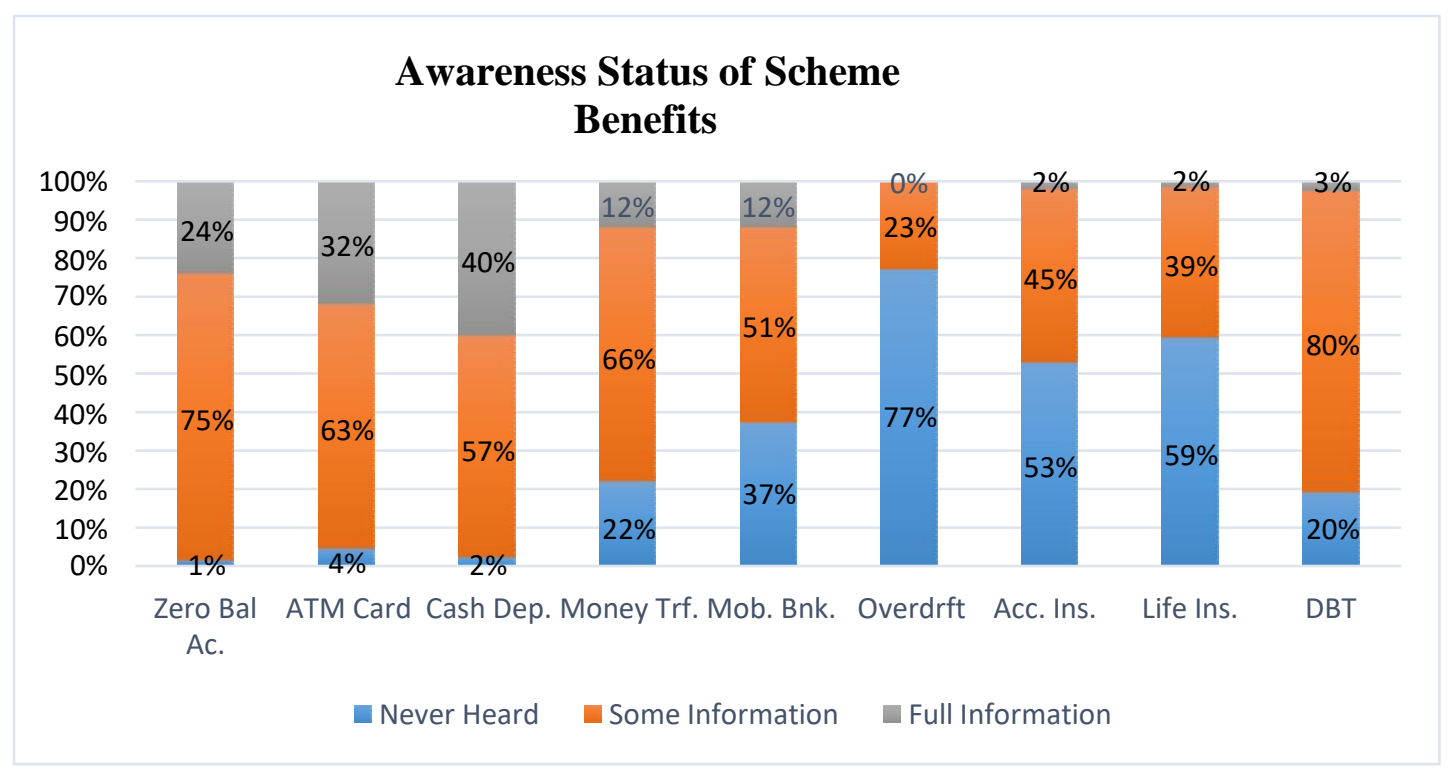

Figure 5. Awareness Status of Scheme Benefits 


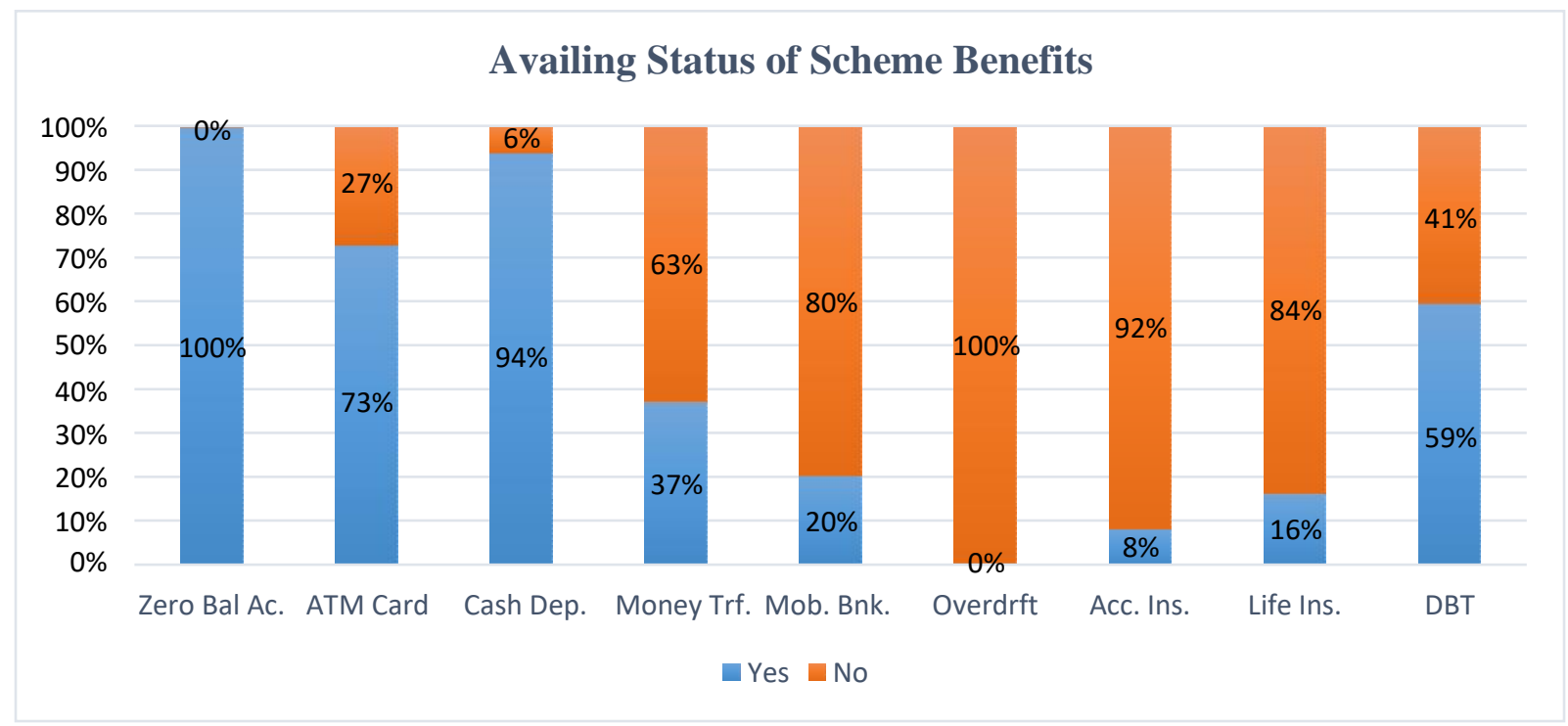

Figure 6. Availing Status of Scheme Benefits

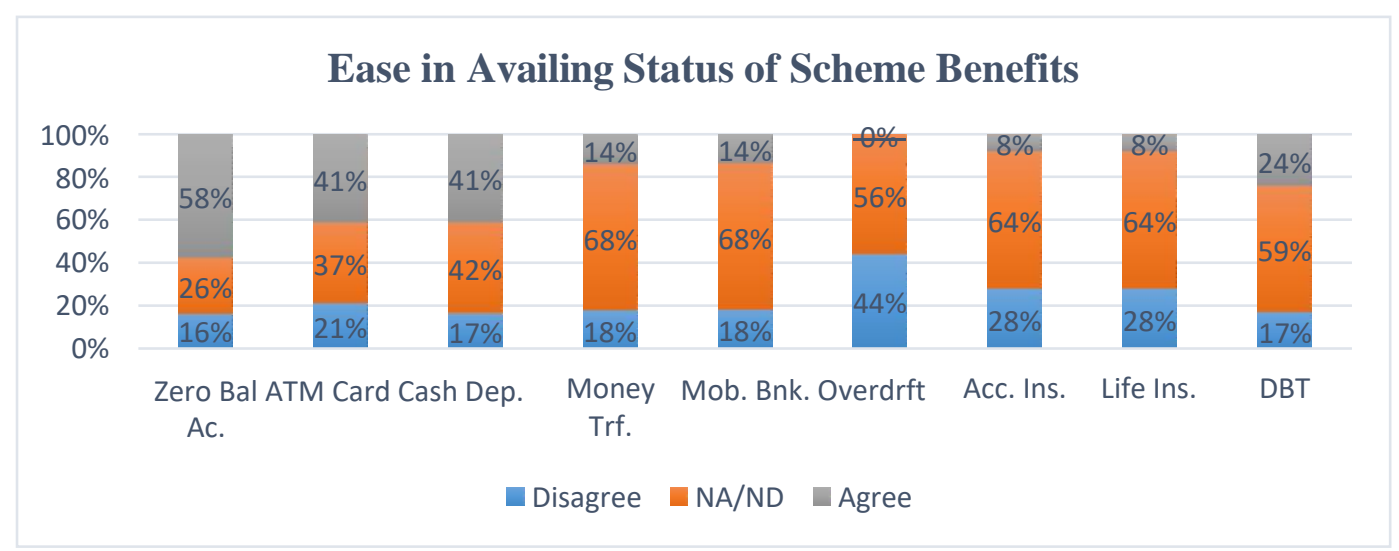

Figure 7. Ease in Availing Status of Scheme Benefits

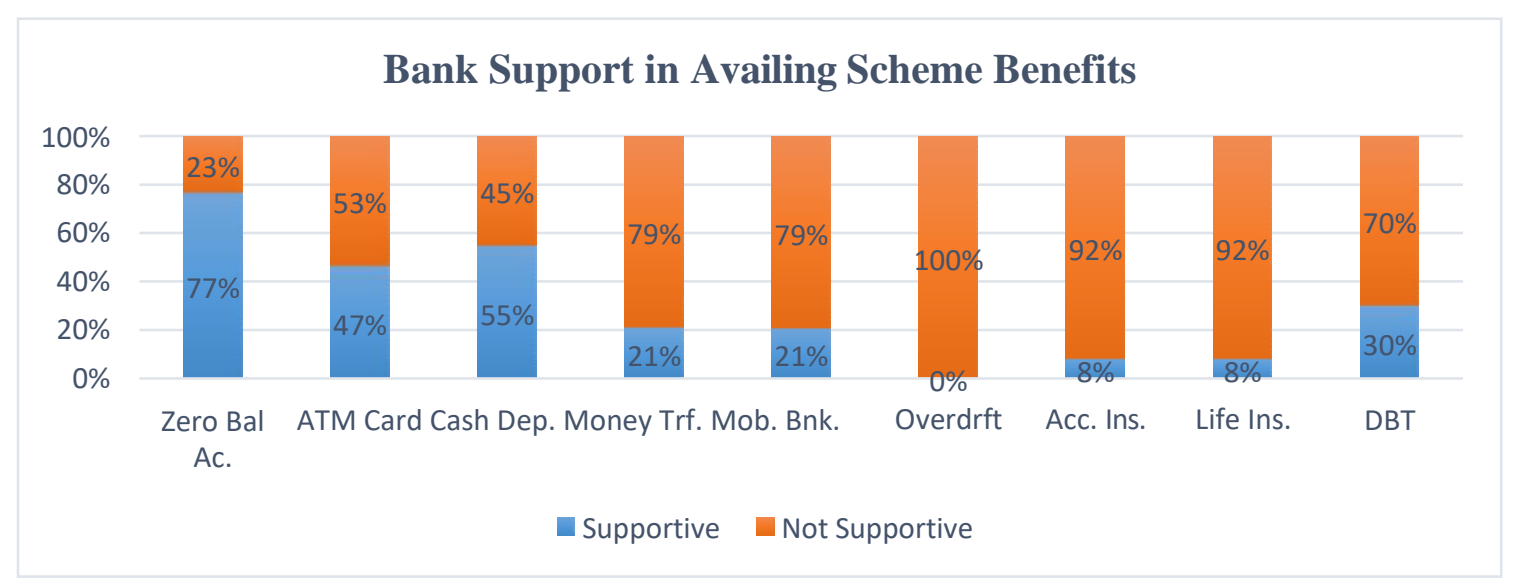

Figure 8. Bank Support in Availing Scheme Benefits 


\section{Local Admin. Support in AvailingScheme Benefits}

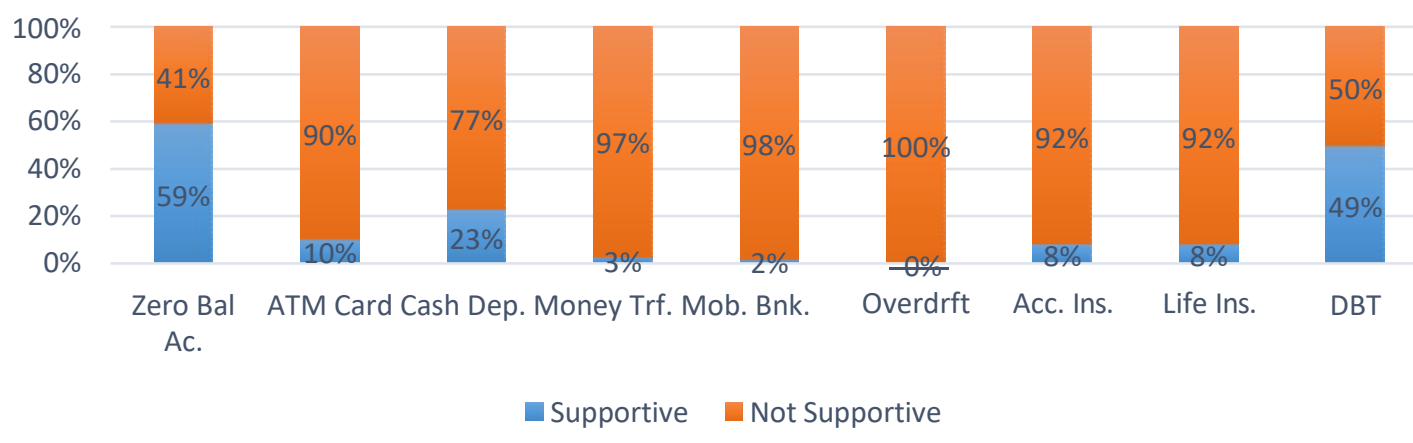

Figure 9. Local Admin. Support in Availing Scheme Benefits

\section{Regression Analysis}

This study attempts to find the factors which affect the availing status of PMJDY scheme benefits in UP Purvanchal region. For this we modelled a multiple regression relationship with Availing status as dependent variable and Awareness, Ease of Availing, Perceived Usefulness to life, Bank support, Local Administration support, facets of scheme benefits as independent variables. The Regression model is as below:

Availing status $=\alpha+\beta_{1}$ Awareness $+\beta_{2}$ Ease of Availing $+\beta_{3}$ Perceived Usefulness to life $+\beta_{4}$ Bank support $+\beta_{5}$ Local Administration support $+\beta_{6}$ facets of scheme benefits.

where, $\beta_{1}, \beta_{2}, \beta_{3}, \beta_{4}, \beta_{5}$ and, $\beta_{6}$ are regression coefficients and $\alpha$ is the constant.

The results of the regression model are as below:

Table 1. Regression Statistics

\begin{tabular}{|l|r|}
\hline \multicolumn{2}{|c|}{ Regression Statistics } \\
\hline Multiple R & 0.7740 \\
\hline R Square & 0.5991 \\
\hline Adjusted R Square & 0.5981 \\
\hline Standard Error & 0.1071 \\
\hline Observations & 2446 \\
\hline
\end{tabular}

Table 2. ANOVA

\begin{tabular}{|l|r|r|r|r|r|}
\hline ANOVA & & & & & \\
\hline & df & SS & MS & F & $\begin{array}{c}\text { Significance } \\
\text { F }\end{array}$ \\
\hline Regression & 6 & 41.80341699 & 6.967236 & 607.4789055 & 0 \\
\hline Residual & 2439 & 27.9731343 & 0.011469 & & \\
\hline Total & 2445 & 69.77655129 & & & \\
\hline
\end{tabular}

Table 3. Regression statistics (*significant at 5\% level of significance)

\begin{tabular}{|l|r|r|}
\hline & $\begin{array}{c}\text { Standardised } \\
\text { Coefficients }\end{array}$ & \multicolumn{1}{|c|}{ P-value } \\
\hline Intercept & 2.260782396 & 0 \\
\hline Facets of scheme benefits & $-0.023440527^{*}$ & $1.10402 \mathrm{E}-11$ \\
\hline Awareness & $-0.39746214^{*}$ & $7.7209 \mathrm{E}-246$ \\
\hline
\end{tabular}




\begin{tabular}{|l|r|r|}
\hline Ease of Availing & 0.000726611 & 0.94363492 \\
\hline Perceived Usefulness to life & $-0.029772597 *$ & $1.73378 \mathrm{E}-08$ \\
\hline Bank support & $0.098524834 *$ & $9.48922 \mathrm{E}-12$ \\
\hline Local Administration support & $0.10507261 *$ & $2.0908 \mathrm{E}-09$ \\
\hline
\end{tabular}

The results of regression analysis in table 3 indicate that the availing status of PMJDY scheme is affected by the independent variables incorporated in equation. This is evident from significant F-score in table 2 and about $60 \%$ (value of Adjusted R Square in table 1) variation in availing status is happening because of the independent variable taken. The influence of each independent factor is as below:

- Facets of scheme benefits: The relationship of this variable is significant with Availing status. The sign of relationship is negative because the dependent variable is reversely coded for avoiding the questionnaire being monotonous. i.e. Yes was coded as 1 and No was coded as 2 . This shows that as more the scheme benefits are recognised, more the scheme will be availed.

- Awareness: The relationship of this variable is significant with Availing status. The sign of relationship is negative because the dependent variable is reversely coded as mentioned above. This shows that augmented awareness about scheme benefits among people will positively affect the availing status of the scheme benefits.

- Ease of Availing: The relationship of this variable is found not significant with Availing status.

- Perceived Usefulness to life: The relationship of this variable is significant with Availing status. The sign of relationship is negative because the dependent variable is reversely coded as mentioned above. This shows that as more people start perceiving the scheme to be useful, they tend to start availing the scheme at higher level.

- Bank support: The relationship of this variable is significant with Availing status. The sign of relationship is positive because both the dependent variable and independent variable is reversely coded for the reason mentioned above. Here Bank being supportive is coded as 1 and not supportive is coded as 2 . This shows that more bank support in availing the facilities will certainly increase the availing status of scheme.

- Local Administration support: The relationship of this variable is significant with Availing status. The sign of relationship is positive because both the dependent variable and independent variable is reversely coded for the reason mentioned above. Here Local Administration being supportive is coded as 1 and not supportive is coded as 2 . This shows that more local administration support in availing the facilities will certainly increase availing status of scheme. Therefore we find that the availing status of PMJDY scheme majorly depends on two factors i.e.Enhanced awareness and local administration support if available.

Next we try to examine the relationship between the availing statuses of PMJDY scheme with various facets of benefits perceived by people. This will help us to understand that how different related perceived facets of benefits relate to availing status of PMJDY scheme.

For this we have modelled a multiple regression relationship with Availing status as dependent variable and facets of benefits i.e. standard of living, prevention of exploitation, improving financial literacy, safety of money, making transactions online and investment opportunities as independent variables. The regression model is as below:

Availing status $=\gamma+\alpha_{1}$ standard of living $+\alpha_{2}$ prevention of exploitation $+\alpha_{3}$ improving financial literacy $+\alpha_{4}$ safety of money $+\alpha_{5}$ online transactions $+\alpha_{6}$ investment opportunities.

The results of the regression model are as below:

Table 4. Regression statistics

\begin{tabular}{|l|r|}
\hline \multicolumn{2}{|c|}{ Regression Statistics } \\
\hline Multiple R & 0.465656 \\
\hline R Square & 0.216835 \\
\hline
\end{tabular}




\begin{tabular}{|l|r|}
\hline Adjusted R Square & 0.214909 \\
\hline Standard Error & 0.149684 \\
\hline Observations & 2446 \\
\hline
\end{tabular}

Table 5. ANOVA

\begin{tabular}{|l|r|r|r|r|r|}
\hline ANOVA & & & & & \\
\hline & df & SS & MS & F & Significance F \\
\hline Regression & 6 & 15.13003 & 2.521672 & 112.548 & $1.3 \mathrm{E}-125$ \\
\hline Residual & 2439 & 54.64652 & 0.022405 & & \\
\hline Total & 2445 & 69.77655 & & & \\
\hline
\end{tabular}

Table 6. Regression statistics (*significant at 5\% level of significance)

\begin{tabular}{|l|r|r|}
\hline & Coefficients & \multicolumn{2}{|c|}{ P-value } \\
\hline Intercept & 1.530533 & 0 \\
\hline standard of living & $-0.02572^{*}$ & $1.98 \mathrm{E}-07$ \\
\hline prevention of exploitation & $-0.04114^{*}$ & $5.91 \mathrm{E}-23$ \\
\hline improving financial literacy & $-0.06037^{*}$ & 0.115208 \\
\hline safety of money & 0.013182 & $2.94 \mathrm{E}-10$ \\
\hline online transactions & $-0.04521^{*}$ & $1.05 \mathrm{E}-85$ \\
\hline investment opportunities & $-0.12846^{*}$ & \\
\hline
\end{tabular}

The results of regression analysis in table 6 indicate that the availing status of PMJDY scheme is affected by the independent variables incorporated in equation. This is evident from significant F-score in Table 5 and about 21\% (value of Adjusted R Square in table 4) variation in availing status is happening because of the independent variable taken. The influence of each independent factor is as below:

- Standard of living: The relationship of this variable is significant with Availing status. The sign of relationship is negative because the dependent variable is reversely coded for avoiding the questionnaire being monotonous. i.e. Yes was coded as 1 and No was coded as 2 . This shows that as more the scheme is perceived to improve the standard of living, more it will be availed by people.

- Prevention of exploitation: The relationship of this variable is significant with Availing status. The sign of relationship is negative because the dependent variable is reversely coded as mentioned above. This shows that more people will avail the scheme if they feel that the scheme benefits will prevent them from getting exploited in the hands of money lenders.

- Improving financial literacy: The relationship of this variable is significant with Availing status. The sign of relationship is negative because the dependent variable is reversely coded as mentioned above. This shows that higher financial literacy created by the scheme will result in increased availing of the scheme.

- Safety of money: The relationship of this variable is found not significant with Availing status.

- Online transactions: The relationship of this variable is significant with Availing status. The sign of relationship is negative because the dependent variable is reversely coded as mentioned above. This shows that people consider cashless transactions as an essential benefit and thus, they will avail the PMJDY scheme more when online transaction facility is available.

- Easy investment opportunities: The relationship of this variable is significant with Availing status. The sign of relationship is negative because the dependent variable is reversely coded as mentioned above. This shows that a higher level of investment opportunity created by the scheme will result in increased availing of the scheme. 
- Therefore we find that people might be most inclined to welcome a financial inclusion scheme if they perceive it to be a beneficial investment opportunity.

\section{DISCUSSION}

After the detailed data analysis above, this section discusses the results. The results show that the beneficiaries are aware about basic banking facilities like zero balance account, ATM debit card, and cash deposit/withdrawal. This shows that scheme has created enough financial literacy about these basic facilities. Financial literacy has been found to have a positive impact on the "use of financial services" (Grohmann, Klühs \& Menkhoff, 2018). However, it was found that other banking facilities like money transfer and mobile banking are little known to people and hence the availing status is quite low. This might be because the results indicate that the banks and local administration have been supportive to people for the basic banking facilities only and not for others. This is also evident from the results of 'Ease in usage' of facilities wherein beneficiaries feel it is easy to use basic banking facilities but not the other facilities. The results on financial security benefits under PMJDY scheme, namely Accidental and Life insurance, show that beneficiaries have some awareness about the availability of such benefits. There are very few people who feel that they have complete information to make a decision and benefit from them. Thus although such schemes are very beneficial to them, the availing status of these services was very low. Regarding ease of use for these benefits, the opinion was quite mixed and most people were undecided. This may be because of lack of awareness among beneficiaries. Another reason that comes out from results is that the support of banks and local administration is not present, resulting in low level of awareness and availing status. PMJDY provides for overdraft facility against the zero balance account opened. From the results it was found that most people have never been told about this facility and its benefits. Therefore in spite of being one of the major scheme benefit under PMJDY, intended to help people in times of need by giving them credit facility has not penetrated the UP Purvanchal region population. This may be attributed to either low emphasis by the authorities, lack of interest by banks or inability of banks/administration in creating financial literacy about such facility. The PMJDY scheme also incorporates other banking facilities like money transfer and mobile banking. It was seen that the awareness regarding these modern facilities are moderate with majority having at least some information. Even the support of banks and local administration is found to be low. Overall this suggests that although people are financially literate about these benefits, but they are unwilling to avail them because of lack of emphasis and support by authorities. Since the Government of India started the financial inclusion process through direct benefit transfer scheme in 2013 , i.e. well before the launch of PMJDY and there has been a lot of media coverage and awareness campaign on the same, hence we find that majority of people have some information about this benefit under PMJDY. The availing status of various banking benefits under PMJDY scheme suggests that majority of people have been availing the basic banking facilities like zero balance account, ATM debit card, cash deposit/withdrawal and they also find using these facilities somewhat easy. However, in case of other banking services like mobile banking and money transfer, similar trend is not shown. Here the availing status and ease of use is found to be low. Credit facilities have not been emphasised much, resulting into very usage of the same. Similarly, financial security benefits are not popular, and evidence of their usage is not present. Overall awareness and availing of banking services under PMJDY scheme has been initiated but not uniformly. Although people have started being financially literate, but still, for complete usage of all banking facilities under PMJDY scheme, there is a long way to go.

\section{Implications for Policy Makers}

Since financial literacy is not uniform across different financial services for enhanced financial inclusion, therefore the policymakers should take necessary steps for augmenting awareness among people regarding all types of banking services. The results of this study suggests that accessibility of financial services at ground level is not uniform. The policymakers should ensure unimpeded accessibility of financial services like credit facility, financial security products and other banking services. The DBT is one of the ambitious scheme of the government for financial inclusion and 
uninterrupted subsidy transfer to needy. The authorities have laid lot of emphases through media coverage and administrative support. Linking DBT with PMJDY accounts is a right step and theresults show that the efforts have been successful to a great extent. In rural areas there are few ATM due to which everyone may not access ATM or may don't know how to use. And secondly, rural areas need to be connected through a complete banking system which throws up connectivity-related challenges that need to be addressed. The policymakers need to address the issue of banking infrastructure by providing support to them.

\section{Implications for Banks/Financial Institutions}

Study reveals that on ground there were very few financial literacy program conducted in their villages. There should be proper awareness programs in remote locations about the financial schemes so that everyone must aware about need of opening account for realising various benefits available under the scheme. The study found that the support given by banks for various banking services under PMJDY is not uniform. Those services where the support was given, were availed most while rest had low availing status. The banks should ensure higher level of support for other essential services like credit facility, financial security schemes and mobile banking etc. Since people have mentioned that they were not accessing many financial services due to difficulty in use of those services. Therefore, banks should review their procedures for offering various financial services other than basic banking facilities under the financial inclusion scheme for ensuring easy accessibility of Banking Services. Many benefits like ATM card transactions require adequate infrastructure facilities, especially in rural areas. Therefore banks should ensure presence of ATM networks in rural areas and provide adequate training. New age technology solutions like mobile banking need to be supported through easy to use interface and training so that higher usage of banking facilities is ensured.

\section{Future Research Directions}

The study indicates several areas of research which merit investigation in future studies. In future the researchers can undertake such research in other regions of the country to compare the extent of financial inclusion achieved through PMJDY scheme. Since this study suggests that there bank's support for various financial services are low therefore as next step a survey may be conducted over Banks/Financial institutions for exploring the problems they are facing while implementing the PMJDY scheme. A longitudinal study may be undertaken further, to assess the change in savings and investment patterns of the urban poor, and thereby gauge the effectiveness of the financial awareness programs undertaken by various agencies. Seasonal changes in savings and usage pattern of bank services could be studied and probable causes for such changes may be analysed. Previous research indicates that women lead households are less likely to have access to formal finance as compared to households with a male head (Swamy, 2014; Ghosh \& Vinod, 2017). Further research can explore factors that provide deeper insights into this. In today's scenario, financial inclusion can help in reducing poverty imposed due to COVID 19 pandemic (Gutiérrez-Romero \& Ahamed, 2021). Further research can explore how it can be successfully implemented to achieve the desired results.

\section{CONCLUSION}

The essence of financial inclusion is to ensure delivery of financial services which include - bank accounts for savings and transactional purposes, low-cost credit for productive, personal and other purposes, financial advisory services, insurance facilities (life and non-life) etc. In India, while one segment of the population has access to banking service encompassing regular banking facilities \& portfolio counselling, the other segment of underprivileged and lower income group is totally deprived of even basic financial services. Exclusion of large segments of the society from financial services affects the overall economic growth of a country. It is for this reason that Financial Inclusion is a national concern. Complete access to financial services is not possible without people being financially literate. Hence, financial inclusion will be successful only when the easy accessibility to financial services is complemented by financial awareness and understanding. Therefore, as revealed by this study policy 
makers and banks should go hand in hand for creating financial literacy and ensuring uniform accessibility of all financial services through adequate support infrastructure. Government should ensure proper implementation of such program by having proper monitoring systems in place. Policy makers should be able to ensure that administrative machinery from top to ground level including panchayat level should be in sync. This will confirm that the scheme benefits should reach to the last person through awareness and accessibility of financial services. The policy makers should leverage technological solution to ensure efficient and effective delivery of financial services.

\section{ACKNOWLEDGEMENT}

The research mentioned in this paper has been carried out with funding received from ICSSR under its first IMPRESS scheme. The authors are thankful to GOI and ICSSR for funding this research.

\section{REFERENCES}

Aghion, P., \& Bolton, P. (1997). A theory of trickle-down growth and development. The Review of Economic Studies, 64(2), 151-172.

Agrawal, A. (2008). The need for financial inclusion with an Indian perspective. Economic Research, 3 , $1-10$.

Ali, M., Nazir, M. I., Hashmi, S. H., \& Ullah, W. (2021). Financial inclusion, institutional quality and financial development: Empirical evidence from OIC countries. The Singapore Economic Review, 1-28.

Allen, F., Demirguc-Kunt, A., Klapper, L., \& Peria, M. S. M. (2016). The foundations of financial inclusion: Understanding ownership and use of formal accounts. Journal of financial Intermediation, 27, 1-30.

Aportela, F. (1999). Effects of financial access on savings by low-income people.

Ashraf, N., Karlan, D., \& Yin, W. (2010). Female Empowerment: Impact of a Commitment Savings Product in the Philippines, World Development. Pergamon, 38(3), 333-344. https://doi.org/10.1016/j.worlddev.2009.05.010.

Banerjee, A. V., \& Newman, A. F. (1993). Occupational choice and the process of development', Journal of Political Economy, 101(2), 274-298. https://doi.org/10.1086/261876.

Beck, T., Demirgüç-Kunt, A., \& Levine, R. (2007). Finance, inequality and the poor, J Econ Growth. Springer New York LLC, 12(1), 27-49. https://doi.org/10.1007/s10887-007-9010-6.

Chakravarty, S. R., \& Pal, R. (2013). Financial inclusion in India: An axiomatic approach. Journal of Policy Modeling, 35(5), 813-837. https://doi.org/10.1016/j.jpolmod.2012.12.007.

Chhabra, N. (2015). Financial inclusion in India. Maharshi Dayanand University, Rohtak. Retrieved from https://shodhganga.inflibnet.ac.in/handle/10603/36960.

Chowhan, S. S., \& Pande, J. C. (2014). Pradhan Mantri Jan Dhan Yojana: A Giant Leap Towards Financial Inclusion, International Journal of Research in Management \& Business Studies, 1(4), 19-22. Retrieved from https://www.academia.edu/download/53996699/IRJMBS.pdf

Cull, R., Ehrbeck, T., \& Holle., N. (2014) Financial inclusion and development: Recent impact evidence. Retrieved from http://www.cgap.org/sites/default/files/FocusNote-Financial-Inclusion-andDevelopment-April-2014.pdf. 
Dangi, N., \& Kumar, P. (2013). Current Situation of Financial Inclusion in India and Its Future Visions',International Journal of Managment and Social Sciences Research, 2(8), 155-166. Retrieved from http://www.irjcjournals.org/ijmssr/Aug2013/23.pdf.

Demirgüç-Kunt, A., Klapper, L. F., Singer, D., \& Van Oudheusden, P. (2015). The global findex database 2014: Measuring financial inclusion around the world. World Bank Policy Research Working Paper, (7255).

Demirgüç-Kunt, A., Honohan, P., \& Beck, T. (2008) Finance for all? Policies and Pitfalls in Expanding access, World Bank Policy Research Report. Retrieved from http://125.234.102.146:8080/dspace/handle/DNULIB_52011/4154

Dupas, P., \& Robinson, J. (2013). Savings constraints and microenterprise development: Evidence from a field experiment in kenya, American Economic Journal: Applied Economics, 5(1), 163-192. https://doi.org/10.1257/app.5.1.163.

Ghosh, S., \& Vinod, D. (2017). What Constrains Financial Inclusion for Women? Evidence from Indian Micro data, World Development. Elsevier Ltd, 92, 60-81. https://doi.org/10.1016/j.worlddev.2016.11.011.

Gloukoviezoff, G. (2007). From financial exclusion to overindebtedness: The paradox of difficulties for people on low incomes?, in New Frontiers in Banking Services: Emerging Needs and Tailored Products for Untapped Markets. Berlin, 213-245. https://doi.org/10.1007/978-3-540-46498-3_6.

Gounasegaran, C., Kuriakose, F., \& Iyer, D. K. (2013). Financial inclusion: Progress so far, facts for you. Banking and Finance. Retrieved from http://www.efymag.com/admin/issuepdf/25- 29_Financial Inclusion_Sep-13.pdf.

Grohmann, A., Klühs, T., \& Menkhoff, L. (2018). Does financial literacy improve financial inclusion? Cross country evidence, World Development. Elsevier Ltd, 111, 84-96. https://doi.org/10.1016/j.worlddev.2018.06.020.

Gutiérrez-Romero, R., \& Ahamed, M. (2021). COVID-19 response needs to broaden financial inclusion to curb the rise in poverty, World Development. Elsevier Ltd, 138, 105229. https://doi.org/10.1016/j.worlddev.2020.105229.

Honohan, P. (2004). Financial Development, Growth and Poverty: How Close are the Links?', in Financial Development and Economic Growth. Palgrave Macmillan UK, 1-37. https://doi.org/10.1057/9780230374270_1.

HR, U., \& KN., R. (2013). The Role of SHGS in Financial Inclusion. A Case Study, International Journal of Scientific and Research Publications, 3(6), 1-5. Retrieved from http://www.ijsrp.org/ejournal.html

Joseph, J., \& Varghese, T. (2014). Role of Financial Inclusion in the Development of Indian Economy', Journal of Economics and Sustainable Development, 5(11), 6-15. Retrieved from https://core.ac.uk/reader/234646410.

Kumar, C., \& Mishra, S. (2011). Banking Outreach and Household level Access : Analyzing Financial Inclusion in India, 13th Annual Conference on Money and Finance, 1-33.

Leeladhar, S. (2006). Taking Banking Services to the Common Man - Financial Inclusion, Reserve Bank of India Bulletin, 9519, 73-77. 
Mialou, A., Amidzic, G., \& Massara, A. (2017). Assessing Countries' Financial Inclusion Standing - A New Composite Index', Journal of Banking and Financial Economics, 2(8), 105-126. https://doi.org/10.7172/2353-6845.jbfe.2017.2.5.

Mohan, B. (2014). Pradhan Manti Jan Dhan Yojana (PMJDY): Features, Needs And Challenges, International Journal of Marketing, Financial Services \& Management Research, 2277-3622.

Mukherjee, A., \& Chakraborty, S. (2012). Financial Inclusion of the poor and Marginalised in Jharkhand: Analysis of the Existing Model. International Journal on Research and Development A Management Review, 1(1).

Paramasivan, C., \& Ganeshkumar, V. (2013). w of Financial Inclusion in India, International Journal of Management and Development Studies, 2(3), 45-49.

PMJDY (2020). Pradhan Mantri Jan-Dhan Yojana| Department of Financial Services Ministry of Finance, Government website. Retrieved from https://www.pmjdy.gov.in/account

Ramji, M. (2009). Financial inclusion in Gulbarga: Finding usage in access, ifmrlead.org. 26. Retrieved from http://ifmr.ac.in/cmf.

Reserve Bank of India (2015). Reserve Bank of India - Reports, RBI report. Retrieved from https://www.rbi.org.in/scripts/PublicationReportDetails.aspx?ID=836\#CH1

Sarma, M. (2008). Index of financial inclusion (No. 215). Working paper.

Sarma, M., \& Pais, J. (2011). Financial inclusion and development. Journal of international development, 23(5), 613-628. https://doi.org/10.1002/jid.1698.

Sen, A. (2000). SOCIAL EXCLUSION: CONCEPT, APPLICATION, AND SCRUTINY. Retrieved from https://www.think-asia.org/handle/11540/2339

Shylendra, H. S. (2006). Microfinance Institutions in Andhra Pradesh', Economic and Political Weekly, 1959-1963. Retrieved from https://www.jstor.org/stable/4418232

Singh, C., Mittal, A., Garg, R., Goenka, A., Goud, R., Ram, K., ... \& Kumar, U. (2014). Financial inclusion in India: Select issues. IIM Bangalore research paper, (474).

Sriram, M. S. (2012). The AP microfinance crisis 2010: discipline or death?, Vikalpa, 37(4), 113-128. Sriram, M., \& Sundaram, N. (2015). Financial Inclusion Index: A Customized Regional Model with

Reference to Economically Most Backward Districts of Tamil Nadu, India, print) Mediterranean Journal of Social Sciences, 6, 2039-2117. https://doi.org/10.5901/mjss.2015.v6n6p209.

Suryanarayana, M. H. (2008). What Is Exclusive about'Inclusive Growth'?, Economic and Political Weekly, 93-101. Retrieved from https://www.jstor.org/stable/40278108

Swamy, V. (2014). Financial Inclusion, Gender Dimension, and Economic Impact on Poor Households, World Development. Pergamon, 56, 1-15. https://doi.org/10.1016/j.worlddev.2013.10.019. 
The World Bank (TWB) (2020). Population, total - India | Data', The World Bank. Retrieved from https://data.worldbank.org/indicator/SP.POP.TOTL?locations=IN

\section{Copyrights}

Copyright for this article is retained by the author(s), with first publication rights granted to the journal. This is an open-access article distributed under the terms and conditions of the Creative Commons Attribution license (https://creativecommons.org/licenses/by/4.0) 